\section{IJ§ER}

ISSN: 2149-5939
International Journal of Social Sciences and Education Research

Online, http://dergipark.gov.tr/ijsser

Volume: 1(2), 2015

\title{
A study on determining attitudes and behaviors of individuals towards local products in Manisa Province: The case of Mesir Paste
}

\author{
Rüveyda Kızıloğlu ${ }^{1} \quad$ Nuray Kızılaslan ${ }^{2} \quad$ Tayfur Ünal $^{3}$
}

Received Date: $01 / 02$ / 2015

Accepted Date: $01 / 04$ / 2015

\begin{abstract}
Some of the local products are region specific and the region is remembered with them. There are also local products with a long past which are not only known in their environs but also famous in other places. Mesir paste, which is one of these products, is traditional food produced by mixing a lot of spices and herbs. With this sense, this study aims to investigate the preferences (packaging, product range demand, quality, hygiene, etc.) of the individuals living in the area since they are significant in determining the attitudes and behaviors towards local products. The study covers some suggestions by determining the attitudes and behaviors of individuals and their desires and expectations so that local products can be protected and be sustainable. First, the knowledge, attitudes and behaviors of individuals in purchasing mesir paste were analyzed using 5-point Likert scale with 13 variables and the variables were collected under a factor with the help of factor analysis. The factor loads listed under a factor as a result of factor analysis were analyzed as one of the independent variables affecting the awareness level of the individuals about the local product. In the research, Binary Logit model was used to determine the factors affecting the local product preferences of the individuals. The awareness level about local products decreased as the age increased, and this may have stemmed from the fact that young people preferred mesir paste more. The packaging of the product in question was also one of the possible influential variables on awareness level. The packaging, which is also valued by manufacturers, as revealed by the study as well, has a positive influence on individuals, and it is a variable that is important in preferring a product.
\end{abstract}

Keywords: Local product, behavior, knowledge, factor analysis, Mesir Paste

\section{Introduction}

Local values contribute to the local economic growth as a supporting element of the economy. Values such as local food, local architecture, local crafts, etc. sometimes undertake that region's name and sometimes take on the promotional activities of the region in addition to making up the alternative income resources of the local residents. Local resource values consist of a past cultural heritage (Kesici, 2012). Many products in Turkey are known to belong only to some specific regions (Kuşat, 2012). For example, mesir paste is a food product specific to Manisa Province. The literal meaning of mesir in the Dialects of Turkey Turkish Dictionary of TLA (Turkish Language Association) is defined as "the name of gummy and spicy candy thrown from minarets in spring fest, and the name of the day this candy is distributed on". Geographical indications add marketing power to a product, and they contribute to rural development and country economy since they aren't a monopoly right, but a collective right protecting the real manufacturers of the product. Individuals may prefer products sold under the name of a given geographical area due to trust in that name to those manufactured in other places. Therefore, protecting the name of a place as a geographical indication which has become a quality symbol for a specific product is of great

\footnotetext{
${ }^{1}$ Asst. Prof. Dr., Department of Agricultural Economics, Faculty of Agriculture, Gaziosmanpasa Un., TOKAT, TURKEY, ruveyda.kiziloglu@gop.edu.tr

${ }^{2}$ Prof. Dr., Department of Agricultural Economics, Faculty of Agriculture, Gaziosmanpasa Un., TOKAT, TURKEY

${ }^{3}$ Department of Agricultural Economics, Faculty of Agriculture, Gaziosmanpasa Un., TOKAT, TURKEY
} 
Kızıloğlu, R., Kızılaslan, N., Ünal, T. (2015). A Study on Determining Attitudes and Behaviors of Individuals towards Local Products in Manisa Province: The Case of Mesir Paste. International Journal of Social Sciences and Education Research, 1 (2), 599-611.

significance in terms of protecting the interests of the local people of the region. Another purpose and benefit of geographical indication protection is to help prevent individuals from deception and therefore help protect individuals by blocking the use of geographical indications and expressions on fake products lacking necessary properties (Anonim, 2014a). Mesir paste is a traditional food produced by mixing many spices and herbs. Knowing the rheological properties of products liquid or semi-liquid in nature manufactured on an industrial scale is of great importance in terms of processing of the product and ensuring its quality control (Karaman et al., 2008). When considered from this point of view, this study aims to determine individuals' (living in the region) preferences (packaging, product range demand, quality, hygiene, etc.) and their attitudes and behaviors towards local products.

In line with the significance and interest of the study, mesir paste indirectly affects the economy of Manisa Province and the country as well. Held every year on a regular basis, the festival provides a great deal of benefit for Manisa Province. Besides, it contributes to religious tourism as it is believed to have healing properties, health tourism as it is thought to be a food product and a source of healing, and other tourism types such as tradition and gastronomy tourism. In addition, the study will determine the attitudes and behaviors of the individuals and cover some suggestions by identifying the requests and expectations of them.

The related literature was reviewed and it was found that Kesici studied the rural tourism in 2012 and investigated the general role of local food and beverage culture already having a wide range to increase the demand for this touristic product in Turkey. In another study, Kuşat tried to determine the economic contribution expected from traditional food in local and national development in the long run by measuring the innovation capacity of traditional products in 2012. In a similar study in 2012, Şahin and Meral discussed the importance of geographical indication and its role in rural development in general terms. Orhan did a compilation study giving brief information on what needs to be done to transform the local values into a tourism value as well as informing shortly about "geographical indications" issued in 2010 to protect local products.

\section{Material and method}

\subsection{Material}

The material of this study was made up of data collected from individuals in the central county of Manisa Province through questionnaires.

\subsection{Data collection method}

The aim was to cover the whole population in this way. In order to determine the number of the individuals to be included in the survey, their rates in total individuals were taken into consideration (Pazarlioglu et al., 2007; Armagan and Akbay 2007; Kiziloglu and Kizilaslan, 2013), and individuals participating were identified randomly.

In order to determine the sample size representing the main mass, proportional sampling method was used (Newbold, 1995).

$$
\mathrm{n}=\frac{N p(1-p)}{(N-1) \sigma_{p}^{2}+p(1-p)}
$$


Kızıloğlu, R., Kızılaslan, N., Ünal, T. (2015). A Study on Determining Attitudes and Behaviors of Individuals towards Local Products in Manisa Province: The Case of Mesir Paste. International Journal of Social Sciences and Education Research, 1 (2), 599-611.

In the equation above, $\mathrm{n}$ represents sample size, $\mathrm{N}$ represents population size (301.218) (TURKSTAT, 2011), p represents estimation rate (sample size 0.5 maximum), $\sigma_{p}^{2}$ represents rate variances (in order to reach maximum sample size, table value should have confidence interval of $95 \%$, with 1.96 and $5 \%$ margin of error). As the characteristics of the enterprises which formed the main mass were not identified in the beginning, $\mathrm{p}$ was determined as 0.5 to maximize the sample size and it was determined as 382 subjects.

\subsection{Data analysis method}

Logit model was used to analyze the socio-economic factors affecting individuals' consumption of local products in the urban areas of Manisa Province. Binary choice models were used for econometrics applications in which dependent variables are qualitative and bivalent, and the most common of them are probit and logit models. The main difference between probit and logit models results from the distribution of error term. While the distribution of error term in the logit model is accepted logistically, it is assumed that error term is normally distributed in the probit model (Greene, 2011; Gujarati, 2001). The logistic regression procedure is the most frequently used method to study individuals' perceptions and behaviors (Gempesaw et al., 1995). A choice model is specified with a dichotomous dependent variable representing the individuals' final choice to be explained by a set of variables such as demographic factors, socio-economic factors, perception, experience, and preferences. Dependent variable is a dummy and estimated likelihood values change between 0 and 1. The estimation method utilizes the Maximum Likelihood Estimation (MLE) procedure as they provide consistent parameter estimates that are asymptotically efficient (Amemiya, 1983; Grimm and Yarnold, 1995; Tabachnick and Fidell, 1996; Tatlidil, 1996; Akkuş and Çelik, 2004; Hatırlı et al., 2004; Leech, Barrett and Morgan, 2005; Cankurt et al., 2010; Kalayc1, 2010).

The logit model for a representative household $i$ can be expressed as follows (Gujarati, 2001);

$$
F_{i}\left(\beta X_{i}\right)=\frac{\exp \left(\beta X_{i}+\varepsilon_{i}\right)}{1+\exp \left(\beta X_{i}+\varepsilon_{i}\right)}
$$

where $\mathrm{F}\left(\beta \mathrm{X}_{\mathrm{i}}\right)=$ index function (preferences for the studied local products for $\mathrm{I}^{\text {th }}$ individual, $\mathrm{j}=0$ represents no preference and $\mathrm{j}=1$ represents preference)

$\beta=$ The coefficient vector of the explanatory variables

$\mathrm{X}_{\mathrm{i}}=$ The explanatory variables representing the characteristics of individuals

$\varepsilon_{\mathrm{i}}=$ Error term

In order to understand logistic coefficients, one needs to think in terms of odds ratio of a happening (Akgül abd Çevik, 2005). When estimating the parameters of the logistic regression model, obtained by taking the natural logarithm of the odds ratio, the maximum likelihood method is widely used (Berenson and Levine, 1996). Some variables included in the logistic model were translated into categorical variables in order to obtain the differences between categories as odds ratios. Some of the independent variables were taken into the model as dummies to provide convenience of interpretation. Education was coded as 1 for high school and over and 0 for lower than high school. Employment was coded as 1 for the employed couples (the interviewed and the spouse), 0 for unemployed couples. Having children was coded as 1 and 0 for no children. The 
Kızıloğlu, R., Kızılaslan, N., Ünal, T. (2015). A Study on Determining Attitudes and Behaviors of Individuals towards Local Products in Manisa Province: The Case of Mesir Paste. International Journal of Social Sciences and Education Research, 1 (2), 599-611.

children were divided into five groups based on an age range in order to investigate whether age had an influence on the person interviewed. Age groups with children were coded as 1, and no children 0 . The age groups were classified as 0-2, 3-6, 7-10, 11-16, and 17 and over. Dummy variables with categorical structure were used for variables representing the effect of gender and marital status. Age and income factors taken into consideration to investigate the factors effecting individuals' preferences towards local products were analyzed as continuous variables.

Binary logit model was used in the study to determine the factors affecting the individuals' local product preferences. The individuals interviewed appropriately to determine dependent variables in the model were divided into two categories: those who purchased and consumed local products to protect the traditions and those who did not. That is, the group with individuals sensitive to and consuming local products was coded as 1 and the other as 0 . The group with low level or no awareness of local products was taken as reference in the model. Therefore the analysis was done based on low level or no awareness for local products taking the group with high level of awareness for local products as a reference. Since the $\mathrm{P}$ value of the created model is less than 0,05 , the model can be considered in $95 \%$ confidence interval.

Table 1 presents explanations about the dependent and explanatory variables used in the analysis and descriptive statistics.

The answers to questions determining the importance level given to features in individuals' knowledge, attitude and behaviors about mesir paste were measured with 5-point Likert scale. As the states showing the scaled purchasing behaviors and attitudes outnumbered, it was impossible to use each one as explanatory variable. Therefore the variables had to be presented in summary. The summary of the variables were obtained using factor analysis and this factor was used as an explanatory variable in Logit analysis (Dölekoğlu and Yurdakul, 2004).

Factor analysis is a kind of multi-variable statistical analysis providing the presentation of data more meaningfully and in a summary format based on the relations between variables (Kurtuluş 2004; Tekin 2007; Karpati and Szakal 2009). The main purpose of this analysis is to interpret each factor individually by explaining the relationship between the original variables with a group of factors with minimum loss of data. In short, factor analysis makes it possible to work with less data while retaining the original data as much as possible. It is usually not possible to measure the behavior of individuals with a single question. Several factors affecting this behavior have a close connection. The purpose of factor analysis is to help work with fewer factors by reducing the data loss as much as possible and bringing the close factors together (Ness, 2000; Kizlloğlu et al., 2015).

\section{Research findings}

\subsection{The general characteristics of the individuals}

Table 1 shows some of the socio-economic and demographic characteristics of the subjects interviewed. $50,3 \%$ of the subjects were females and $49,7 \%$ males. $58,9 \%$ of the individuals were married and $41,1 \%$ single. The mean age of the subjects interviewed was 42,13 . 
Kızıloğlu, R., Kızılaslan, N., Ünal, T. (2015). A Study on Determining Attitudes and Behaviors of Individuals towards Local Products in Manisa Province: The Case of Mesir Paste. International Journal of Social Sciences and Education Research, 1 (2), 599-611.

Table 1. The general characteristics of the individuals and some statistical findings

\begin{tabular}{|c|c|c|c|c|c|}
\hline \multicolumn{2}{|c|}{ Variables, Groups and Descriptions } & Frequency & $\%$ & Std.Dev & Mean \\
\hline \multicolumn{6}{|l|}{ Dependent variable } \\
\hline \multicolumn{2}{|c|}{ With high levels of awareness of local products: 1} & 193 & 50,5 & \multirow{2}{*}{0,501} & \\
\hline Low level or no awarenes & of the local product: 0 & 189 & 49,5 & & \\
\hline \multicolumn{6}{|c|}{ Explanatory Variables } \\
\hline Age & \multicolumn{4}{|l|}{ Continuous variable } & 42,13 \\
\hline \multirow{2}{*}{ Gender } & Female: 0 & 192 & 50,3 & \multirow{2}{*}{0,501} & \\
\hline & Male: 1 & 190 & 49,7 & & \\
\hline \multirow{2}{*}{ Marital status } & Single: 0 & 157 & 41,1 & \multirow{2}{*}{0,493} & \\
\hline & Married: 1 & 225 & 58,9 & & \\
\hline \multirow{2}{*}{ Educational status } & Under high school: 0 & 177 & 46,3 & \multirow[b]{2}{*}{0,499} & \\
\hline & High school or above: 1 & 205 & 53,7 & & \\
\hline \multirow[t]{2}{*}{ employment status } & $\begin{array}{l}\text { Not working (retired, un- } \\
\text { employed, looking for } \\
\text { work, students): } 0\end{array}$ & 142 & 37,2 & \multirow[t]{2}{*}{0,484} & \\
\hline & Working: 1 & 240 & 62,8 & & \\
\hline \multirow{2}{*}{$\begin{array}{l}\text { spouse employment sta- } \\
\text { tus }\end{array}$} & No: 0 & 247 & 64,7 & \multirow{2}{*}{0,479} & \\
\hline & Yes: 1 & 135 & 35,3 & & \\
\hline \multirow{2}{*}{ Children } & With no children: 0 & 152 & 39,8 & \multirow{2}{*}{0,490} & \\
\hline & With children: 1 & 230 & 60,2 & & \\
\hline \multirow{2}{*}{$0-2$ year-old } & With no children: 0 & 371 & 97,1 & \multirow{2}{*}{0,167} & \\
\hline & With children: 1 & 11 & 2,9 & & \\
\hline \multirow{2}{*}{ 3-6 year-old } & With no children: 0 & 365 & 95,5 & \multirow{2}{*}{0,206} & \\
\hline & With children: 1 & 17 & 4,5 & & \\
\hline \multirow{2}{*}{$7-10$ year-old } & With no children: 0 & 366 & 95,8 & & \\
\hline & With children: 1 & 16 & 4,2 & 0,201 & \\
\hline 11_16 vear-old & With no children: 0 & 353 & 92,4 & 0265 & \\
\hline 11-10 year-ord & With children: 1 & 29 & 7,6 & 0,205 & \\
\hline 16 - $00+1$ & With no children: 0 & 201 & 52,6 & 0.400 & \\
\hline 16 years or older & With children: 1 & 181 & 47,4 & 0,499 & \\
\hline Income & Continuous variable & & & & $3,290.00$ \\
\hline & No purchases: 0 & 282 & 73,8 & & \\
\hline Consumption Frequency & $\begin{array}{l}\text { Purchase at least once a } \\
\text { week: } 1\end{array}$ & 100 & 26,2 & 0,440 & \\
\hline Hoolina nronertiec & No: 0 & 206 & 53,9 & 0400 & \\
\hline Healing properties & Yes: 1 & 176 & 46,1 & 0,499 & \\
\hline Reasonable nrice & No: 0 & 301 & 78,8 & 0.400 & \\
\hline Reasonable price & Yes: 1 & 81 & 21,2 & 0,409 & \\
\hline Beneficial & No: 0 & 212 & 55,5 & 0.498 & \\
\hline Beneficial & Yes: 1 & 170 & 44,5 & 0,498 & \\
\hline 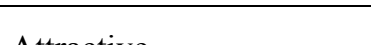 & No: 0 & 247 & 64,7 & 0.170 & \\
\hline Attractive & Yes: 1 & 135 & 35,3 & $0,4 / 9$ & \\
\hline Packared nroduct & No: 0 & 33 & 8,6 & 0281 & \\
\hline Packaged product & Yes: 1 & 349 & 91,4 & 0,281 & \\
\hline Intoroct hu bildron & No: 0 & 123 & 32,2 & $0-168$ & \\
\hline minerest oy cmilaren & Yes: 1 & 259 & 67,8 & 0,408 & \\
\hline 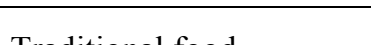 & No: 0 & 16 & 4,2 & $0001+4$ & \\
\hline Traditional food & Yes: 1 & 366 & 95,8 & 0,201 & \\
\hline $\begin{array}{l}\text { Factor 1: Purchasing cri- } \\
\text { teria }\end{array}$ & continuous variable & & & & \\
\hline
\end{tabular}


Kızıloğlu, R., Kızılaslan, N., Ünal, T. (2015). A Study on Determining Attitudes and Behaviors of Individuals towards Local Products in Manisa Province: The Case of Mesir Paste. International Journal of Social Sciences and Education Research, 1 (2), 599-611.

The educational status of the interviewed individuals was classified into two groups as under high school for literate, elementary and secondary school, and high school and above for high school, undergraduate, graduate and postgraduate. While under high school group made up 46,3 $\%$, high school and above group constituted $53,7 \%$. As for the employment status of the subjects interviewed, the unemployed were $37,2 \%$, and the employed were $62,8 \%$. Among the unemployed were students, housewives, retired, and those unemployed but receiving an income. The employed spouses made up 35,3\% and the unemployed $64,7 \%$.

While $39,8 \%$ of the subjects interviewed had no children, $60,2 \%$ had children. According to the age range statistics of the children, the rate of the subjects with 0-2 year-old children was 2.9 $\%$, 3-6 year-old $4.5 \%, 7-10$ year-old $4.2 \%, 11-16$ year old $7.6 \%$, and 16 and over $47.4 \%$. The mean score for monthly income of the subjects interviewed was determined to be TL 3,290.00. The rate of the subjects who bought mesir paste at least once a week was found to be $26,2 \%$ when compared to that of who did not. When the mesir paste consumption reason of the individuals interviewed was examined, it was found that $46,1 \%$ bought it for its healing properties, $21,2 \%$ for reasonable price, $44,5 \%$ for its benefits, $35,3 \%$ due to its attractiveness, $91,4 \%$ because it is a packaged product, $67,8 \%$ due to their children's interest, and $95,8 \%$ because it is traditional food.

\subsection{Knowledge of the Individuals about Mesir Paste}

Knowledge of the individuals about mesir paste varied. Knowledge of the place of mesir paste supply, packaged consumption, brand preferences, and usage patterns by consumers will provide benefits for the manufacturers. Table 2 presents proportional values about mesir paste supply. According to the table, the most preferred supply point for mesir paste was markets with 54,97 $\%$. It is thought that while doing a routine shopping in a market, mesir paste is also bought from the same market for practical reasons such as easy transportation and saving time. It was observed that $41,62 \%$ of the subjects preferred herbalists. Mesir paste is usually marketed as packaged.

Table 2. Locations where the subjects usually bought mesir paste ${ }^{*}$

\begin{tabular}{|l|r|r|}
\hline Supply points & \multicolumn{1}{|c|}{$\begin{array}{c}\text { Fre- } \\
\text { quency }\end{array}$} & \multicolumn{1}{c|}{$\%$} \\
\hline Wholesale and retail shops & 38 & 9,94 \\
\hline Herbalists & 159 & 41,62 \\
\hline Market & 210 & 54,97 \\
\hline Confectioners & 86 & 22,51 \\
\hline *Other & 27 & 7,06 \\
\hline
\end{tabular}

* The other group involves places selling mesir paste such as groceries, liquor stores, market stands, and market departments of gas stations.

Table 3 presents individuals' reasons for consuming packaged mesir paste. When the individuals' reasons for consuming packaged mesir paste are examined, it can be seen that $45,54 \%$ was habit, and $15,18 \%$ preferred it when they couldn't find the product unpackaged. As there are various companies manufacturing mesir paste, they have all become brands. The existence of various brands has led the consumer to different brand preferences. 
Kızıloğlu, R., Kızılaslan, N., Ünal, T. (2015). A Study on Determining Attitudes and Behaviors of Individuals towards Local Products in Manisa Province: The Case of Mesir Paste. International Journal of Social Sciences and Education Research, 1 (2), 599-611.

Table 3. Reasons for packaged mesir paste consumption

\begin{tabular}{|l|r|r|}
\hline \multicolumn{1}{|c|}{ Reasons } & Frequency & \% \\
\hline Habit & 154 & 40,31 \\
\hline Freshness & 50 & 13,08 \\
\hline Reliability & 174 & 45,54 \\
\hline Can't find unpackaged & 58 & 15,18 \\
\hline *Other & 19 & 4,97 \\
\hline
\end{tabular}

* Among the other packaged mesir paste consumption reasons are mesir paste is available packaged in markets, hygiene, healthy, and easy to consume.

Table 4 shows information about whether individuals preferred a certain mesir paste brand. $51,05 \%$ of the individuals cared about a certain brand and made brand-based preferences. Therefore, companies should increase promotions and give enough importance to quality.

Table 4. Brand preferences for Mesir Paste

\begin{tabular}{|l|r|r|}
\hline \multicolumn{1}{|c|}{ Reasons for brand preference } & Frequency & \% \\
\hline Yes & 195 & 51,05 \\
\hline No & 187 & 48,95 \\
\hline
\end{tabular}

Table 5 presents the individuals' reasons for brand preferences. The leading reason for brand preference was quality and freshness with $32,98 \%$. Price and visual factors were not found as significant as quality and freshness. Mesir paste is consumed in different forms. Companies produce mesir paste in various forms as a result of marketing research due to its high consumption potential and promotion.

Table 5. Individuals' reasons for brand preferences

\begin{tabular}{|l|r|r|}
\hline \multicolumn{1}{|c|}{ Reasons for preference } & Frequency & \multicolumn{1}{c|}{$\%$} \\
\hline Availability & 42 & 10,99 \\
\hline Packaged & 51 & 13,35 \\
\hline Appealing & 17 & 4,45 \\
\hline Quality and freshness & 126 & 32,98 \\
\hline Appropriate price & 20 & 5,23 \\
\hline *Other & 70 & 18,32 \\
\hline
\end{tabular}

Table 6 presents individuals' mesir paste consumption patterns. Mesir paste, as the name suggests, is mostly consumed as paste $(50,00 \%)$. This is followed by as delight $19,63 \%$, as tea $18,58 \%$, and as chocolate $17,27 \%$.

Table 6. Individuals' mesir paste consumption patterns

\begin{tabular}{|l|r|c|}
\hline \multicolumn{1}{|c|}{ Consumption pattern } & Frequency & \% \\
\hline Paste & 191 & 50,00 \\
\hline Sugar & 50 & 13,08 \\
\hline Chocolate & 66 & 17,27 \\
\hline Delight & 75 & 19,63 \\
\hline Tea & 71 & 18,58 \\
\hline Mash & 39 & 10,20 \\
\hline Cezerye (a mixture of various herbs and spices) & 46 & 12,04 \\
\hline
\end{tabular}

\subsection{Individuals' knowledge, attitudes and Behaviors on Mesir Paste purchase}

5-point Likert scale was used to determine individuals' knowledge, attitude and behaviors about mesir paste purchase. To determine the attitudes and behaviors, factor analysis was performed to investigate whether 11 features could be put into one group. As a result of the analysis, 
Kızıloğlu, R., Kızılaslan, N., Ünal, T. (2015). A Study on Determining Attitudes and Behaviors of Individuals towards Local Products in Manisa Province: The Case of Mesir Paste. International Journal of Social Sciences and Education Research, 1 (2), 599-611.

it was concluded that 11 features could be gathered under one factor with title "purchase criteria". To understand whether sampling was adequate, KMO value was examined. In other words, KMO test was done to understand whether the model was acceptable. This value needs to be greater than 0,600 (Tabachnick and Fidell, 2001). As KMO value approaches 1, it indicates that data is suitable for analysis, and a KMO value of 1 indicates a perfect sampling number. The KMO coefficient in this study was 0,937, which meant a very good sampling (Field, 2000; Keleş, 2007; Yılmaz, 2009; Kızıloğlu et al., 2013) (Table 7).

Table 7. KMO and Barlett test for Individuals' knowledge, attitudes and behaviors on Mesir Paste purchase

\begin{tabular}{|l|l|l|}
\hline Kaiser-Meyer-Olkin Measure of Sampling Adequacy. & 0,937 \\
\hline \multirow{3}{*}{ Bartlett's Test of Sphericity } & Approx. Chi-Square & 4053,175 \\
\cline { 2 - 3 } & df & 55 \\
\cline { 2 - 3 } & Sig. & 0,000 \\
\hline
\end{tabular}

As a result of eigenvalues statistics and screen plot examination in factor analysis of individuals" "knowledge, attitude and behaviors on mesir paste purchase", 11 titles were gathered under one factor. The first factor, total and cumulative variance, was found to explain $68,47 \%$ of the total variance. Finally rotated component matrix (converted matrix) was formed. This matrix is the final result of factor analysis. The correlation between the original variable and its factor is given in the matrix. A variable is closely associated with a factor under which that variable has a great weight as absolute value (Kalayc1, 2010).

Table 8. Individuals' knowledge, attitudes and behaviors about Mesir Paste purchase

\begin{tabular}{|c|c|c|c|c|c|c|}
\hline \multirow{2}{*}{ Component } & \multicolumn{3}{|c|}{ Initial Eigen values } & \multicolumn{3}{c|}{ Extraction Sums of Squared Loadings } \\
\cline { 2 - 7 } & Total & $\begin{array}{c}\text { \% of Vari- } \\
\text { ance }\end{array}$ & Cumulative \% & Total & $\begin{array}{c}\text { \% of Vari- } \\
\text { ance }\end{array}$ & Cumulative \% \\
\hline 1 & 7,532 & 68,468 & 68,468 & 7,532 & 68,468 & 68,468 \\
\hline
\end{tabular}

(Factor number and variance based on eigenvalues statistics for individuals' knowledge, attitudes and behaviors on mesir paste purchase)

It was understood from the rotated component matrix factor loads in Table 9 that the 11 variables of "Individuals' knowledge, attitudes and behaviors about mesir paste purchase" could be gathered under one title "Purchase Criteria", that is, under 1 factor load.

Table 9. Consumers' knowledge, attitudes and behaviors about mesir paste purchase, alternating load factor (Rotated Component Matrix)

\begin{tabular}{|l|r|}
\hline \multicolumn{1}{|c|}{ Variable classes } & $\mathbf{1}$ \\
\hline Sold in packages & 0,911 \\
\hline hygienic & 0,900 \\
\hline high nutritional value & 0,890 \\
\hline natural and pure product & 0,889 \\
\hline a source of healing & 0,889 \\
\hline expiration date is important & 0,879 \\
\hline preferred by many people & 0,812 \\
\hline consumption habits & 0,773 \\
\hline has an appropriate price & 0,751 \\
\hline high quality product advertising & 0,691 \\
\hline appealing package & 0,670 \\
\hline
\end{tabular}


Kızıloğlu, R., Kızılaslan, N., Ünal, T. (2015). A Study on Determining Attitudes and Behaviors of Individuals towards Local Products in Manisa Province: The Case of Mesir Paste. International Journal of Social Sciences and Education Research, 1 (2), 599-611.

\subsection{Some factors affecting the individuals' preferences}

Table 10 presents some socio-demographic features and appendices of the results of the analysis affecting the individuals' level of consciousness towards local products. After determining the level of consciousness, the factors statistically affecting the level of consciousness were studied. The variables likely to affect the level of consciousness towards local products were analyzed.

It was determined as a result of binary logit analysis that the age, gender, employment of the individual interviewed, having 0-2 and 3-6 year old children, consumption frequency, healing properties, benefits, packaged product consumption, children's interest, and traditional food were variables likely to affect the level of consciousness.

While the employment status, found significant at $5 \%$ significance level, affected preference level negatively, benefits, packaged product consumption, and children's interest affected it positively. That is, the unemployed individuals were expected to be $12 \%$ more fond of local products than those employed. Or a variance of one unit in unemployed individuals was likely to change the level of consciousness $12 \%$.

The individuals considering local products beneficial were expected to prefer local products $10 \%$ more than those who did not. That is, it can be stated with this study that the benefits of mesir paste was statistically determined to have a positive effect on individuals' mesir paste preference. Individuals who wanted to buy packaged local products for health reasons were $45 \%$ more likely to prefer consuming the local product than those who didn't care about packaging. That is, an increase of one unit in the individuals who preferred buying packaged local products was expected to change the likelihood of local product consumption $45 \%$. As a result of the research, it was found that the likelihood of local product consumption due to children's interest was $10 \%$ more than lack of likelihood of consumption.

While the gender of the individuals and healing property of the product, found significant at 1 $\%$ significance level, had a positive effect on the preference level of the local product, the age of the individuals, having 3-6 year old children and the consumption frequency variables were expected to affect the level of preference negatively. A change of one unit in individuals' age was expected to affect the likelihood of local product consumption $1 \%$. That is, as the age of the individuals increased, the likelihood of local product consumption was expected to decrease. Males were $15 \%$ more likely to consume local products than females. Individuals with 3-6 yearold children were $42 \%$ less likely to consume the local product than those who didn't have this age range of children. It can be said that people who did not buy the product once a month were $28 \%$ more likely to prefer local products than those who did. That is, this study determined that there was not a direct relationship between the purchasing frequency of a product and preference of it. Table 10 shows that the purchasing frequency of a product and preference of the product, which were not directly related, were positively correlated with healing properties of the product. That is, individuals' local product preference due to its healing properties was $21 \%$ more likely when compared to opting out.

Individuals having 0-2 year-old children, found to be significant at $10 \%$ significance level, were expected to be $32 \%$ less likely to prefer local products than those who didn't have this age range of children. That's, a variance of one unit in individuals with $0-2$ year-old children was 
Kızıloğlu, R., Kızılaslan, N., Ünal, T. (2015). A Study on Determining Attitudes and Behaviors of Individuals towards Local Products in Manisa Province: The Case of Mesir Paste. International Journal of Social Sciences and Education Research, 1 (2), 599-611.

expected to decrease local product preference $32 \%$. Individuals' mesir paste consumption because it is traditional food was $21 \%$ more than opting out.

Table 10. The Results of Binary Logit Analysis for factors affecting individuals' local product preference

\begin{tabular}{|c|c|c|c|c|c|}
\hline & Coefficient & $\begin{array}{c}\text { Standard } \\
\text { error }\end{array}$ & $\mathrm{Z}$ & $|z| \succ Z *$ & Marginal effect \\
\hline constant & 0.18956 & 1.46679 & 0.13 & 0.8972 & \\
\hline AGE & $-0.04739 * * *$ & 0.01383 & -3.43 & 0.0006 & $-0.00778 * * *$ \\
\hline GENDER & $0.91683 * * *$ & 0.29768 & 3.08 & 0.0021 & $0.15046 * * *$ \\
\hline MD & -0.21753 & 0.40215 & -0.54 & 0.5886 & -0.03570 \\
\hline ED & 0.08112 & 0.31531 & 0.26 & 0.7970 & 0.01331 \\
\hline $\mathrm{CD}$ & $-0.75663 * *$ & 0.34053 & -2.22 & 0.0263 & $-0.12417 * *$ \\
\hline ESCD & 0.29086 & 0.40299 & 0.72 & 0.4704 & 0.04773 \\
\hline CHILD & 0.51853 & 0.83597 & 0.62 & 0.5351 & 0.08510 \\
\hline CHILD 1 & $-1.93100^{*}$ & 1.06387 & -1.82 & 0.0695 & $-0.31690 *$ \\
\hline CHILD 2 & $-2.57022 * * *$ & 0.97067 & -2.65 & 0.0081 & $-0.42180 * * *$ \\
\hline CHILD 3 & -0.46880 & 0.87880 & -0.53 & 0.5937 & -0.07694 \\
\hline CHILD 4 & -0.54732 & 0.66015 & -0.83 & 0.4071 & -0.08982 \\
\hline CHILD 5 & -0.27679 & 0.79239 & -0.35 & 0.7269 & -0.04543 \\
\hline INCOME & -0.04688 & 0.08545 & -0.55 & 0.5832 & -0.00769 \\
\hline FREQUENCY & $-1.69388 * * *$ & 0.32035 & -5.29 & 0.0000 & $-0.27799 * * *$ \\
\hline HEALING & $1.27121 * * *$ & 0.29725 & 4.28 & 0.0000 & $0.20862 * * *$ \\
\hline $\begin{array}{l}\text { APPROPRI- } \\
\text { ATE }\end{array}$ & -0.18125 & 0.32048 & -0.57 & 0.5717 & -0.02975 \\
\hline BENEFICIAL & $0.59622 * *$ & 0.27901 & 2.14 & 0.0326 & $0.09785^{* *}$ \\
\hline $\begin{array}{l}\text { CHILDREN'S } \\
\text { INTEREST }\end{array}$ & -0.38524 & 0.28298 & -1.36 & 0.1734 & -0.06322 \\
\hline PACKAGING & $2.68099 * *$ & 1.33165 & 2.01 & 0.0441 & $0.43998^{* *}$ \\
\hline $\begin{array}{l}\text { ATTRAC- } \\
\text { TIVE }\end{array}$ & $0.62442 * *$ & 0.29234 & 2.14 & 0.0327 & $0.10248 * *$ \\
\hline $\begin{array}{l}\text { TRADI- } \\
\text { TIONAL }\end{array}$ & $-1.25125^{*}$ & 0.70959 & -1.76 & 0.0778 & $-0.20535^{*}$ \\
\hline FACTOR 1 & 0.24930 & 0.27782 & 0.90 & 0.3695 & 0.04091 \\
\hline \multicolumn{6}{|c|}{ Note: $* * *, * *, *==>$ Significance At $1 \%, 5 \%, 10 \%$ Level. } \\
\hline
\end{tabular}

\section{Conclusion and recommendations}

Some local products are region specific and known and remembered with the name of the region. There are also some products coming from the past up to the present and they are not only famous in their region but also well-known in other places as well. This study tried to investigate the views of local people about mesir paste, one of the well-known products, and their attitudes and behaviors towards local products. The interviewed individuals were mainly young and middle aged. The education level of the majority of the subjects was high school or above. That is, the study tried to measure the consciousness level for local products by collecting the views of individuals with high level education.

First, the knowledge, attitudes, and behaviors of individuals in purchasing mesir paste was measured using 5-point Likert scale with 13 variables and the variables were gathered under one factor with the help of factor analysis. The factor loads gathered under one factor as a result of 
Kızıloğlu, R., Kızılaslan, N., Ünal, T. (2015). A Study on Determining Attitudes and Behaviors of Individuals towards Local Products in Manisa Province: The Case of Mesir Paste. International Journal of Social Sciences and Education Research, 1 (2), 599-611.

factor analysis were analyzed as one of the independent variables affecting the individuals' consciousness level about local products.

The consciousness level about the local product decreased as the age increased, and this may have stemmed from the fact that young people prefer mesir paste more. On the other hand, according to the analyses, the consumption preference of children at 0-6 year-old age range was determined to be less than those of older ages. That's, it can be inferred from this finding that the product in question did not appeal to very young and very old age groups, rather it appealed to young age groups. Indeed, it was determined as a result of the analysis that the families with over 0-6 year-old children consumed this product as they loved it. Not only did the age of the children affect the level of consciousness, but the packaging of the product which increased the attractiveness was also one of the variables likely to have an influence. The packaging, which manufacturers also paid attention and gave importance to, was determined by this study once again to make a positive impression on individuals and be a significant variable in the preference of the product. On the contrary of normal products, the consumption frequency of mesir paste, a local product, and its consumption preference were found to be inversely related. However, the consumption likelihood of the local product turned out to be much due to its healing properties and benefits, but it was statistically determined that it was not preferred due to considerations that it is a traditional product. We can therefore say that the individuals living in the area were not inclined to consume it just because it is a traditional product; instead they wanted to consume it due to its healing properties and benefits.

It was determined as a result of the research findings and analyses that the state of individuals' local product preferences stemmed from their will to protect the product, however the age range of the children dominated their preferences, that is, affected the preferences. In line with these findings, it can be recommended that companies and manufacturers should consider children of all ages as well as adults when manufacturing the product.

\section{References}

Akgul, A. and Cevik, O. (2005). Statistical Analysis Techniques. Emek Offset Ltd. Sti. 2nd Edition. P. 428. Ankara.

Akkus, Z. and Celik, M.Y. (2004). Significant in logistic regression and discriminant analysis. II. National Biostatistics Congress NDA submitted papers. Mersin University, School of Medicine, Department of Biostatistics, Mersin (September-October).

Amemiya, T. (1983). Advanced Econometrics. Cambridge. MA. Harvard University.

Anonim, (2014). Manisa İli yerli ve yabancı turist sayıları toplamı, Manisa İl Kültür Turizm Müdürlüğü verileri

Armagan, G. and Akbay, C. (2007). An econometric analysis of urban households' animal products consumption in Turkey. Applied Economics. 1-8.

Berenson, M.L. and Levine, D.M. (1996). Basic Business statistics concepts and applications. sixth ed.. p. 837. Prenticehall international. New York.

Cankurt, M., Miran, B. and Sahin, A. (2010). Determining of the Effective Factors on Cattle Meat Preferences: the Case of Izmir. Animal Production 51: 16-22. 
Kızıloğlu, R., Kızılaslan, N., Ünal, T. (2015). A Study on Determining Attitudes and Behaviors of Individuals towards Local Products in Manisa Province: The Case of Mesir Paste. International Journal of Social Sciences and Education Research, 1 (2), 599-611.

Dolekoglu, C. and Yurdakul, O. (2004). Determination Of Affecting Factors And Nutrition Level By Logit Analysis In The Household Of Adana Province. Mediterranean Journal of Economics and Administrative Sciences of Faculty, 8: 62-86.

Field, A., (2000). Discovering Statistics Using SPSS for Windows. London: SAGE Publication.

Gempesaw, II.C.M., Bacon, J.R., Wessells, C.R. and Manalo, A. (1995). Consumer perceptions of aquaculture products. American Journal of Agricultural Economics. 77: 1306-1312.

Greene, W.H. (2011). Econometric Analysis. Seventh Edition. Prentice Hall. ISBN-10: 0131395386. New Jersey.

Grimm, L.G. and Yarnold, P.R. (1995). Reading and understanding multivariate statistics. Washington D.C.: American Psychological Association.

Gujarati, N.D. (2001). Essential of Econometrics, Mc Graw Hill, New York. (Translate: Senesen, U., Senesen, G.G.), Literatür Publication No:33,Istanbul.

Hatirli, S.A., Demircan, V. and Aktas, A.R. (2004). Analysis of Fish Consumption of Family in Isparta. Süleyman Demirel University Faculty of Economics and Administrative Sciences, 9: 245-256.

Kalayc1, S. (2010). SPSS Applied Multivariate Statistical Techniques. BRC Printing, Ankara.

Karaman, S., Kesler, Y., Kayacier, A. and Dogan, M. (2008). Mesir Macununun Reolojik Özelliklerinin Belirlenmesi, Türkiye 10. Glda Kongresi; 21-23 Mayıs 2008, Erzurum,

Karpati, L. and Szakal, Z., (2009). Marketing Characteristics of Tokaj Wine Specialities Based on Factor and Cluster Analyses. Applied Studies in Agribusiness and Commerce - APSTRACT Agroinform Publishing House, Budapest. p: 93-102.

Keles, C., (2007). Get an Application with the effect of culture on consumption of green products and green products Depletion of Green Marketing Consumer Behavior. Institute of Social Sciences, Department of Business Administration (M.Sc.).

Kesici, M., (2012). The Role of Traditional Food and Beverage Culture Concerning to Demand of Rural Tourism. KMU Social and Economic Research Journal 14 (23): 33-37.

Kiziloglu, R. and Kizilaslan, H. (2013). Consumer behaviors on food purchasing places: A case study of red meat consumption in Turkey", Research\&Reviews in Biosciences (RRBS), ISSN: 0974-7532, 7 (11), 453-459.

Kiziloglu, R., Kizilaslan, H. and Erumit, İ. (2015). A Study on Determining the Consumer Awarness Level and Attitudes About Genetically Modified Organisis(The Case of Gerze County of Sinop Province). Journal of Agricultural Faculty of Gaziosmanpasa University. 32 (3), 88-97, E-ISSN: 2147-8848.

Kiziloglu, R., Kizilaslan, H., Gokce, C., (2013). Study Related to Informations, Consepts and Attitudes of The Students of Agricultural Faculty in Gaziosmanpasa University About the Green Food Products. Volume: 6, pp: 19-30.

Kurtulus, K. (2004). Marketing Research (Expanded 7th Edition). Literature Publishing, Publication No. 114, pp: 397-418, İstanbul.

Kusat, N. (2012). A Study Based On The Role Of Traditional Food Products On Regional Development and Innovation Characteristics of Traditional Food Products: Example of Afyon. Management and Economics: Celal Bayar University Faculty of Economics and Administrative Sciences Journal 19.2: 261275.

Leech, N.L., Barrett, K.C. and Morgan, G.A. (2005). SPSS for intermediate statistics: Use and interpretation (2nd ed). Mahwah, NJ: Lawrence Erlbaum Associates. 
Kızıloğlu, R., Kızılaslan, N., Ünal, T. (2015). A Study on Determining Attitudes and Behaviors of Individuals towards Local Products in Manisa Province: The Case of Mesir Paste. International Journal of Social Sciences and Education Research, 1 (2), 599-611.

Ness, M., (2000). Multivariate Techniques in Marketing Research. Curso de Especializacion Postuniversitaria en Marketing Agroalimentario, CHIEAM, Spain.

Newbold, P. (1995). Statistics for Business and Economics. New Jersey: Prentice Hall.

Orhan, A., (2010). The Use of Geographical Indications in the Conversion of Local Values to Tourism Products; The Case of İzmit Pişmaniyesi. Anatolia: Journal of Tourism Research, Volume 21, Number 2, Fall: 243-254, 2010.

Pazarlioglu, M.V., Miran, B., Ucdogruk, S. and Akbay, C. (2007). Using econometric modelling to predict demand for fluid and farm milk: A case study from Turkey. Food Quality and Preference. 18: 416-424.

Sahin, A. and Meral, Y., (2012). Turkey’s Geographical Marking and Local Products. Turkish Scientific Collection Journal 5 (2): 88-92.

Stephenson, B. (2008). Binary response and logistic regression analysis. www.public.iastate.edu/ stat415/stephenson/ stat415_chapter3.pdf. adresinden 22 Kasim 2008 tarihinde edinilmiştir.

Tabachnick, B.G. and Fidell, L.S. (1996). Using multivariate statistics (3rd ed.). New York, USA: HarperCollins College Publishers.

Tabachnick, B.G. and Fidel, S.L. (2001). Using Multivariate Statistics, 4th Edition, Boston.

Tatlıdil, H. (1996). Uygulamalı Çok Değişkenli İstatistiksel Analiz. Cem Web Ofset. Ankara.

Tekin, V.N. (2007). SPSS Marketing for Applied Scientific Research. Distinguished Publishing, Ankara.

Yilmaz, V. (2009). Investigation of Turkey streams Multivariate Statistical Analysis of Water Quality Parameters. Selcuk University, Institute of Science, Civil Engineering Department of Business Administration (M.Sc.). 